\title{
Substitusi Tepung Onggok Terfermentasi Dalam Pembuatan Crackers
}

\author{
Substitution of Fermented Cassava Baggase Flour In Cracker Processing
}

\author{
Otik Nawansih'1), Azhari Rangga'), Siti Nurdjanah1), dan Anggy Putri Ernani2) \\ 1)Dosen Jurusan Teknologi Hasil Pertanian Fakultas Pertanian Universitas Lampung \\ 1)Alumni Jurusan Teknologi Hasil Pertanian Fakultas Pertanian Universitas Lampung \\ e-mail : otiknawansih@yahoo.co.id
}

\begin{abstract}
Abstrak
Tepung onggok terfermentasi mengandung pati $46,69 \%$, serat pangan $13,49 \%$ dan protein $6,98 \%$, mempunyai potensi untuk substitusi tepung terigu pada pembuatan crackers. Penelitian ini bertujuan untuk mendapatkan substitusi tepung onggok terfermentasi yang menghasilkan sifat sensori crackers yang masih baik sesuai dengan Standar Mutu Biskuit SNI 2973-2011. Tepung onggok terfermentasi disubsitusikan menggantikan tepung terigu sebesar 0\% (b/b); $5 \%(b / b) ; 10 \%(b / b) ; 15 \%(b / b) ; 20 \%(b / b)$ dan $25 \%(b / b)$. Adonan sesuai resep crackers kemudian dicetak dan dioven. Crackers yang dihasilkan diamati tekstur menggunakan uji skoring sedangkan rasa, aroma, warna dan penerimaan keseluruhan menggunakan uji hedonik. Data dianalisis dengan ANARA dan dilanjutkan dengan uji Orthogonal Contrast (OC) taraf 5\%. Perlakuan terbaik kemudian dilakukan uji proksimat serta dilakukan uji banding dengan crackers yang menggunakan onggok dari industri tapioka yang difermentasi untuk melihat prospek aplikasinya dalam skala industri. Hasil penelitian menunjukkan bahwa crackers dengan substitusi tepung onggok terfermentasi 5\% (b/b) memiliki karakteristik sensori yang masih diterima/disukai yaitu tekstur 3,89 (renyah), rasa 3,59 (suka), warna 3,76 (suka), aroma 3,52 (suka) dan penerimaan keseluruhan 3,66 (suka) serta mengandung kadar air 1,97\%, kadar abu 1,98\%, kadar protein 7,28\%, kadar lemak 15,23\%, karbohidrat 73,54 dan total serat pangan 7,30\%. Kelebihan dari crackers ini adalah kandungan seratnya yang tinggi. Crackers ini mempunyai peluang tinggi untuk dikembangkan dengan memanfaatkan onggok dari industri tapioka yang difermentasi karena hasil uji Crcakers yang dihasilkan memiliki karakteristik yang sama dengan yang disubstitusi dari onggok fermentasi yang dibuat skala laboratorium.
\end{abstract}

Kata kunci: Crackers, sifat sensori, substitusi, Tepung onggok terfermentasi

\begin{abstract}
Solid residue form tapioca industry (baggase) has not been fully utilized as food source. The aim of this research was to substitute wheat flour with fermented cassava baggase flour to produce crackers having good sensory properties, and in accordance with the Quality Standard of Biscuit SNI 2973-2011. The experiment was arranged in a Complete Randomized Block Design (CRBD) with 4 replications. The treatment consisted of 6 levels of fermented cassava baggase flour substitation which were 0\% (w/w); $5 \%$ $(w / w) ; 10 \%(w / w) ; 15 \%(w / w) ; 20 \%(w / w)$ and $25 \%(w / w)$. The crackers's dough was formed and baked, then sensory test wasconducted for texture, flavor, color, aroma and overall acceptance. The data were analysed by ANOVA and then continued tested using Contrast Orthogonal test. The results showed that the crackers with the substitution 5\% of fermented cassava baggase flour had the best treatment. This crackesrs had texture score of 3.89 (crispy), flavor of 3.59 (like), color of 3.76 (like), aroma of 3,52 (like), overall acceptance of 3,66 (like) and contained 1.97\% of moisture, $1.98 \%$ of ash, $7.28 \%$ of protein, $15.23 \%$ of fat, 73.54 of carbohydrates and total dietary fiber of 7,30\%. Crackers with the best treatment applied on fermented baggase flour from tapioca industry had the same sensory properties as crackers with substitution of fermented laboratory prepared baggase flour.
\end{abstract}

Keywords: Crackers, Fermented bagasse cassava flour, Sensory properties

\section{Pendahuluan}

Menurut BPS (2016), produksi singkong Indonesia Tahun 2015 sebesar 21.790.956 ton dan Provinsi Lampung menyumbang produksi sebesar 7.387.084 ton (33,9\%). Industri olahan singkong yang berkembang adalah industri tapioka. Onggok merupakan limbah padat 
industri tapioka dengan persentasi sekitar $60 \%$ dari bahan baku singkong (FAO, 2001).

Onggok mengandung pektin 10,11\%, hemiselulosa $21,8 \%$ dan selulosa $6,31 \%$ (Nurdjanah dan Elfira, 2009). Komponen tersebut merupakan komponen polisakarida non pati, dimana dinding sel nya merupakan komponen terbesar dalam pembentukan dietary fiber (Schmidl dan Labuza, 2000). Salah satu kendala pemanfaatan onggok untuk bahan pangan adalah masih adanya kandungan sianida yang cukup tinggi karena penggunaan singkong pahit sebagai bahan baku industri tapioka.

Menurut Olaoye et al. (2015), salah satu upaya yang dilakukan untuk mengurangi kandungan sianida adalah dengan proses fermentasi seperti yang terjadi dalam pengolahan Garri. Proses fermentasi menggunakan Saccharomyces cerevisiae juga mampu menurunkan kandungan sianida pada onggok sebagai bahan pakan ternak (Kaewongso et al., 2011; Aizah et al., 2017). Menurut Hidayat et al. (2018), proses fermentasi onggok selama 4 hari dengan S.cerevisiae sebanyak $2 \% \quad(\mathrm{~b} / \mathrm{b})$ akan meningkatkan kandungan protein onggok dari 0,92\% menjadi $6,98 \%$ dan menurunkan kandungan HCN onggok dari 30,52 ppm menjadi 8,87 ppm.

Tepung onggok terfermentasi yang kaya serat dapat digunakan sebagai bahan baku crackers. Menurut Standar Mutu Biskuit SNI 2973-2011, crackers adalah jenis biskuit yang terbuat dari adonan yang melalui proses fermentasi atau pemeraman, berbentuk pipih dan rasanya lebih mengarah ke rasa asin dan renyah serta bila dipatahkan penampang potongannya berlapis-lapis.

Crackers biasanya berbahan baku tepung terigu, namun berbagai upaya substitusi telah dilakukan dengan tepung gayam (Jariyah et al., 2013), tepung kedelai (Sulistyowati et al., 2015), dan tepung suweg (Khatarina, 2018). Dalam penelitian ini dilakukan substitusi tepung terigu dengan tepung onggok terfermentasi. Menurut Hidayat et al., (2018), onggok terfermentasi mengandung pati $46,69 \%$, serat pangan $13,49 \%$ dan protein $6,98 \%$ sehingga bila disubstitusikan dalam pembuatan crackers diharapkan dapat menghasilkan crackers kaya serat. Permasalahan yang ada yaitu belum ditemukan substitusi yang tepat untuk menghasilkan crackers yang masih disukai dan sesuai dengan
Standar Mutu Biskuit SNI 2973:2011. Oleh karena itu perlu dilakukan penelitian untuk mengetahui pengaruh substitusi tepung onggok fermentasi terhadap sifat sensori dalam pembuatan crackers.

Pembuatan crackers menggunakan bahan utama tepung terigu. Tepung terigu merupakan salah satu bahan yang membentuk struktur kerangka pembuatan crackers karena mengandung protein glutenin dan gliadin yang membuat adonan elastis, membentuk lembaran, pipih dan dapat menahan $\mathrm{CO}_{2}$ hasil fermentasi yeast (Afianti dan Indrawati, 2015). Beberapa percobaan telah dilakukan untuk substitusi tepung terigu dengan tepung gayam (Jariyah et al., 2013), tepung kedelai (Sulistyowati et al., 2015) dan tepung suweg (Khatarina, 2018). Hasil penelitian tersebut menunjukan hasil substitusi dengan tepung umbi suweg terbaik adalah $10 \%$, demikian juga tepung kedelai dan tepung teri sebesar $10 \%$. Oleh karena itu substitusi tepung onggok terfermentasi hasil penelitian Hidayat et al. (2018) juga mempunyai potensi untuk diaplikasikan dalam pembuatan crackers. Tepung onggok hasil fermentasi dengan Sacharomyces cerevisiae $2 \%(\mathrm{~b} / \mathrm{b})$ selama 4 hari menghasilkan karakteristik tepung dengan derajat putih 52,70\%, kandungan pati $46,69 \%$, serat pangan $13,49 \%$, lemak $0,59 \%$, protein $6,98 \%$ dan kadar $\mathrm{HCN}$ $8,87 \mathrm{ppm}$.

Namun demikian penggunaan tepung onggok fermentasi untuk substitusi tepung terigu dalam pembuatan crackers harus tetap menghasilkan crackers yang masih disukai. Substitusi yang terlalu banyak diduga akan menghasilkan tekstur yang keras akibat berkurangnya glutein dan gliadin yang mampu menahan gas sehingga adonan kurang mengembang. Selain tekstur, rasa, aroma dan warna juga akan dipengaruhi oleh substitusi tepung terkait. Hasil penelitian Jariyah et al. (2013) menunjukan semakin banyak tepung gayam yang disubstitusikan menghasilkan warna crackers yang semakin coklat dan tidak disukai. Demikian juga hasil penelitian Khatarina (2018) menunjukan bahwa semakin banyak tepung suweg yang disubstitusikan menghasilkan rasa dan aroma crackers yang langu dan tidak disukai panelis. Oleh karena itu perlu dicari konsentrasi maksimal tepung onggok fermentasi yang menghasilkan crackers dengan karakteristik sensori yang masih disukai. 


\section{Metode Penelitian}

Bahan yang digunakan adalah Singkong varietas Kasetsart dengan umur panen 9 bulan diperoleh dari Petani Kecamatan Jati Agung Kabupaten Lampung Selatan Provinsi Lampung, onggok basah dari industri tepung tapioka PD. Semangat Jaya Kabupaten Pesawaran Provinsi Lampung, Fermipan (inoculum komersial Sacharomyces cerevisiae), tepung terigu merk Kunci Biru, gula halus merk Ratu, garam, margarin merk Blue Band, susu skim merk Tropicana Slim, air dan baking powder merk Koepoe-koepoe. Bahan kimia yang digunakan untuk analisis adalah aquades, heksane, $\mathrm{H}_{2} \mathrm{SO}_{4}$, $\mathrm{HCl}, \quad \mathrm{CuSO}_{4} . \quad 5 \mathrm{H}_{2} \mathrm{O}_{2}, \quad \mathrm{~K}_{2} \mathrm{SO}_{4}, \alpha$ amilase, amyloglukosidase, $\mathrm{H}_{3} \mathrm{BO}_{4}$, buffer fosfat, etanol, aseton dan indikator PP. Alat utama yang digunakan dalam penelitian adalah blender, slicer, centong, wadah mixer, oven listrik, timbangan, roll penggiling, desikator, neraca analitik, tanur, alat ekstraksi Soxhlet dan reflux.

Percobaan disusun dalam Rancangan Acak Kelompok Lengkap (RAKL) dengan 4 ulangan. Perlakuan berupa factor tunggal yaitu substitusi tepung terigu dengan tepung onggok terfermentasi sebesar 0\%, 5\%, 10\%, 15\%, 20\% dan 25\% (b/b). Homogenitas diuji dengan uji Barlett dan kemenambahan data diuji dengan uji Tuckey. Data dianalisis dengan sidik ragam untuk mendapat pendugaan ragam galat dan uji signifikansi untuk mengetahui pengaruh antar perlakuan. Untuk mengetahui perbedaan antar perlakuan dilakukan uji Orthogonal Contrast (OC) pada taraf 5\%..

\section{Pembuatan tepung onggok terfermentasi (Hidayat et al., 2018)}

Pembuatan tepung onggok terfementasi diawali dengan memperoleh onggok basah yang meliputi proses sortasi dengan memilih singkong segar dan umbi sudah memasuki umur panen 9 bulan, pembersihan (pengupasan dan pencucian), pengecilan ukuran (pemotongan dan penghalusan) dan ekstraksi. Kemudian onggok difermentasi dengan menambahkan $2 \%$ (b/b) dari S.cerevisiae selama 4 hari dengan suasana fakultatif anaerob. Selanjutnya onggok fermentasi dikeringkan pada suhu $50^{\circ} \mathrm{C}$ hingga kadar airnya $\pm 10 \%$, kemudian digiling dan diayak dengan ukuran 80 mesh.

\section{Pembuatan Crackers}

Satu satuan percobaan berbasis $100 \mathrm{~g}$ tepung. Margarin 24g, garam 1 g, gula 2g, susu skim $10 \mathrm{~g}$ dan air $50 \mathrm{ml}$ diaduk sampai rata. Selanjutnya dilakukan pencampuran tahap 1(tepung terigu dan ragi), pencampuran tahap 2 (tepung onggok terfermentasi dan baking powder) sesuai perlakuan sampai kalis, difermentasi selama 60 menit pada suhu ruang, pembentukan lembaran dengan ketebalan $2 \mathrm{~cm}$, penambahan bahan pengisi berupa tepung terigu, pencetakan dengan ukuran seragam, pembentukan lubang sebanyak \pm 10 lubang dan dioven pada suhu $190^{\circ} \mathrm{C}$ selama 20 menit.

\section{Pengamatan}

Tepung onggok terfermentasi dan tanpa fermentasi diamati kadar HCN menggunakan metode titrasi dengan $\mathrm{AgNO}_{3}$ (SNI 7622, 2011). Sedangkan crackers diamati sifat sensori yaitu tekstur dengan metode skoring, kemudian rasa, aroma, warna dan penerimaan keseluruhan dengan metode hedonik (Nurainy dan Nawansih, 2006). Perlakuan terbaik dianalisis sifat kimia meliputi kadar air, kadar abu, kadar lemak dan protein (SNI 01-2891, 1992), karbohidrat dengan metode by different (Andarwulan, dkk., 2011) dan total serat pangan (AOAC 991.43, 1995) dan dibandingkan dengan Standar Mutu Biskuit SNI 2973-2011. Selain itu crackers perlakuan terbaik diterapkan pada onggok industri terfermentasi untuk melihat peluang pemanfaatan onggok industri. Crackers dengan kedua jenis bahan ini karakteristik sensorinya diuji dengan Uji Pasangan Tunggal dengan respon berarah menggunakan panel semi terlatih sebanyak 20 orang.

\section{Hasil Dan Pembahasan}

\section{Kadar HCN Tepung Onggok Terfermentasi}

Tepung onggok fermentasi mengandung HCN lebih rendah (9,8 ppm) dibandingkan tepung onggok tanpa fermentasi (21,57 ppm) atau fermentasi mampu menurunkan 54,57\% HCN. Kadar sianida pada tepung onggok terfermentasi sebesar 9,8 ppm masih memenuhi ambang batas kadar HCN sebesar 10 ppm untuk bahan baku yang digunakan untuk pembuatan produk pangan (FAO, 1989).

\section{Sifat Sensori crackers} Tekstur

Hasil analisis ragam menunjukkan bahwa perlakuan substitusi tepung terigu dengan tepung onggok terfermentasi berpengaruh sangat nyata terhadap kerenyahan crackers yang dihasilkan. Hasil uji lanjut orthogonal contrast menunjukkan bahwa substitusi tepung onggok terfermentasi dapat menurunkan kerenyahan crackers yang dihasilkan (Gambar 
1). Penambahan tepung onggok terfermentasi diduga menyebabkan penurunan total gluten pada adonan yang memberikan dampak terhadap penurunan sifat elastisitas adonan sehingga crackers kurang mengembang dan menjadi keras. Menurut Subandoro et al. (2013), jika jumlah gluten pada adonan sedikit menyebabkan adonan kurang mampu menahan gas, sehingga pori-pori adonan yang terbentuk berukuran kecil-kecil dan kemampuan untuk amengembang menjadi tidak sempurna.

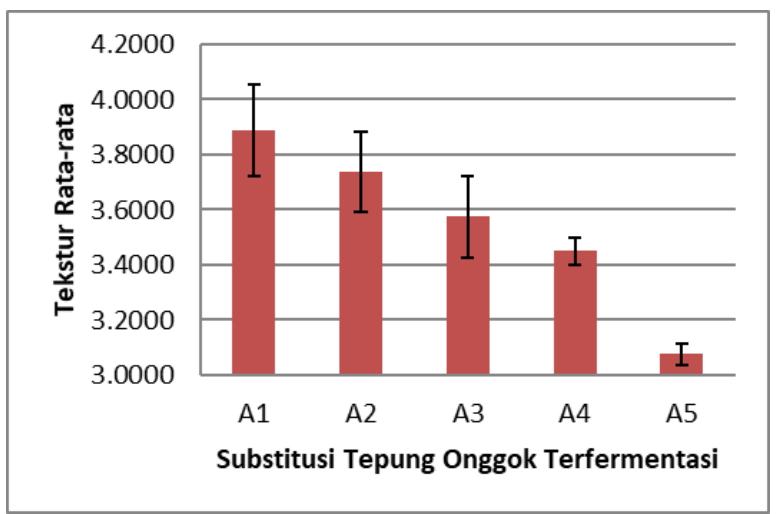

Gambar 1. Pengaruh substitusi tepung terigu dengan tepung onggok terfermentasi terhadap tesktur crackers

Keterangan:

1 = Sangat tidak renyah; 2 = Tidak renyah; 3 = Agak renyah; 4 = Renyah; 5 = Sangat renyah

Substitusi tepung onggok fermentasi : A1 (0\%); A2 (5\%); A3(10\%); A4(15\%); A5(20\%); A6(25\%)

\section{Rasa}

Hasil analisis ragam menunjukkan bahwa perlakuan substitusi tepung terigu dengan tepung onggok terfermentasi berpengaruh sangat nyata pada skor kesukaan terhadap rasa. Hasil uji lanjut orthogonal contrast menunjukkan bahwa crackers dengan substitusi tepung onggok terfermentasi $5 \%$ (b/b) dan 10\% (b/b) memeiliki rasa sama dengan crackers tanpa substitusi tepung onggok terfermentasi A1 (0\%) dengan skor 3,61 (disukai). Substitusi tepung onggok lebih dari 10\% menghasilkan rasa crackers yang kurang disukai. Hal ini diduga dipengaruhi oleh pembentukan senyawa-senyawa hasil metabolisme berupa perombakan karbohidrat menjadi glukosa dan terjadinya peningkatan kadar alkohol serta meningkatnya total asam (Suliantri dan Winiarti, 1991 dalam Fahmi dan Nurrahman, 2011). Pengaruh lain yang menyebabkan terbentuknya rasa asam karena $\mathrm{pH}$ tepung onggok terfermentasi tergolong asam $(5,64)$ sehingga mempengaruhi rasa yang dihasilkan.

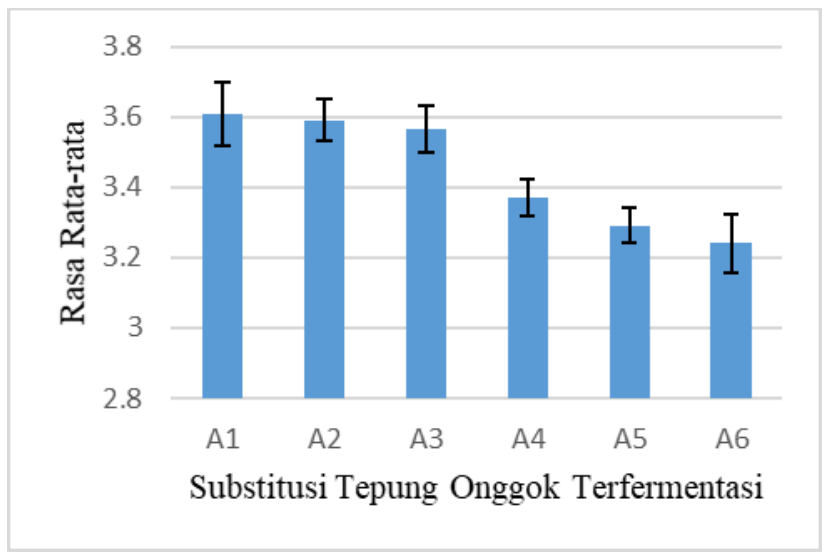

Gambar 2. Pengaruh substitusi tepung terigu dengan tepung onggok terfermentasi terhadap rasa crackers

Keterangan:

1 = Sangat tidak suka; 2 = Tidak suka; 3 = Agak suka; $4=$ Suka; 5 = Sangat suka

Substitusi tepung onggok, $\mathrm{A} 1=0 \%$; $\mathrm{A} 2=5 \%$; A3 $=10 \% ; A 4=15 \% ; A 5=20 \%$; $A 6=25 \%$

\section{Aroma}

Hasil analisis ragam menunjukkan bahwa perlakuan substitusi tepung terigu dengan tepung onggok terfermentasi berpengaruh sangat nyata terhadap skor kesukaan aroma crackers yang dihasilkan. Hasil uji lanjut orthogonal contrast, menunjukkan bahwa crackers dengan substitusi tepung onggok terfermentasi $5 \% \quad(\mathrm{~b} / \mathrm{b})$ memiliki aroma crackers sama dengan crackers tanpa substitusi tepung onggok terfermentasi yaitu disukai. Aroma yang terbentuk pada crackers hasil penelitian ini diduga merupakan kombinasi dari tepung terigu dengan tepung onggok terfermentasi serta bahan lain seperti margarin. Semakin banyak persentase tepung onggok terfermentasi yang disubstitusikan maka aroma crackers cenderung tidak disukai. Aroma asam yang dihasilkan diduga karena $\mathrm{pH}$ tepung onggok terfermentasi tergolong asam yaitu sebesar 5,64 sesuai dengan hasil penelitian Hadi (2017), dimana fermentasi pati singkong dengan S.cerevisiae menghasilkan penurunan $\mathrm{pH}$ menjadi 5,6. Sedangkan aroma harum khas crackers disebabkan oleh penambahan margarin. Menurut Okaviana et al. (2017), penambahan margarin mampu menutupi aroma pada tepung mocaf dan tepung pisang kepok pada pembuatan cookies. Pengaruh substitusi tepung terigu dengan tepung onggok terfermentasi terhadap aroma crackers disajikan pada Gambar 3. 


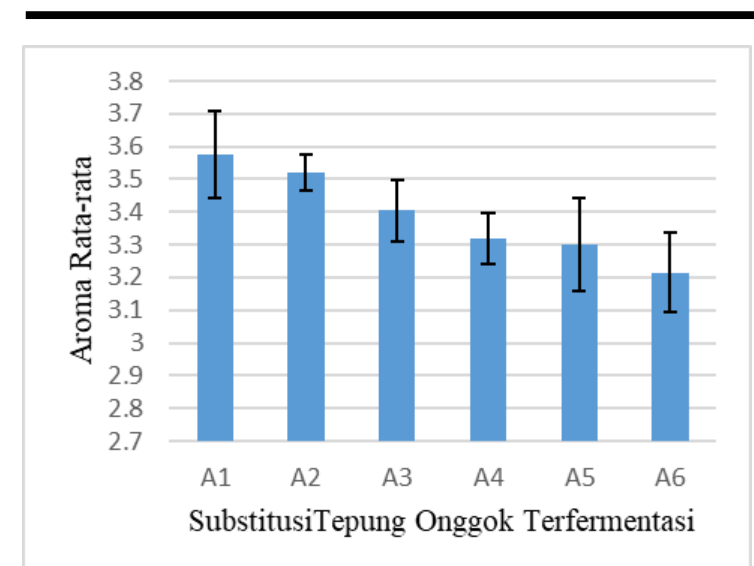

Gambar 3. Pengaruh substitusi tepung terigu dengan tepung onggok terfermentasi terhadap aroma crackers

Keterangan:

1 = Sangat tidak suka; 2 = Tidak suka; 3 = Agak suka; 4 = Suka; 5 = Sangat suka

Substitusi tepung onggok, $A 1=5 \%$; $A 2=10 \%$; $\mathrm{A} 3=15 \% ; \mathrm{A} 4=20 \% ; \mathrm{A} 5=25 \%$

\section{Warna}

Hasil analisis ragam menunjukkan bahwa perlakuan substitusi tepung terigu dengan tepung onggok terfermentasi berpengaruh sangat nyata terhadap kesukaan warna crackers yang dihasilkan. Hasil uji lanjut orthogonal contrast menunjukkan bahwa crackers dengan substitusi tepung onggok terfermentasi 5-10\% memiliki warna sama dengan crackers tanpa substitusi onggok terfermentasi (A1, 0\%) yaitu disukai.

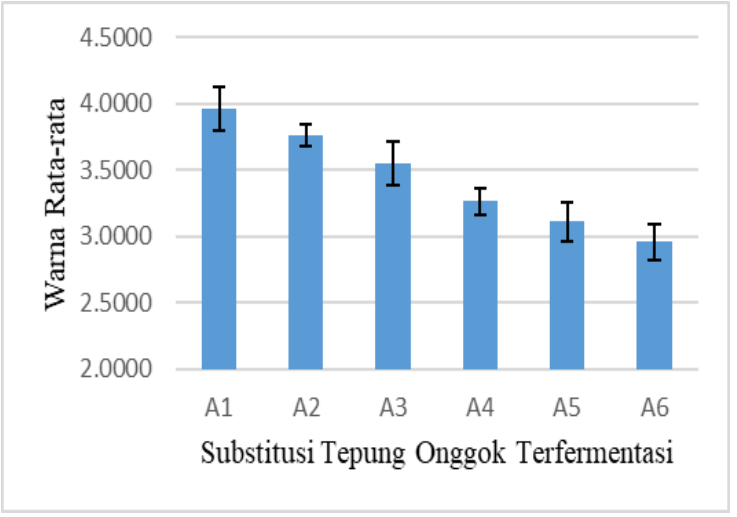

Gambar 4. Pengaruh substitusi tepung terigu dengan tepung onggok terfermentasi terhadap warna crackers

Keterangan:

1 = Sangat tidak suka; 2 = Tidak suka; 3 = Agak suka; $4=$ Suka; 5 = Sangat suka

Substitusi tepung onggok, A1=0\%; A2=5\%; $\mathrm{A} 3=10 \% ; \mathrm{A} 4=15 \% ; \mathrm{A} 5=20 \%$; A6 $=25 \%$

Penambahan tepung onggok terfermentasi menyebabkan penurunan skor kesukaan terhadap warna crackers yang berwarna kecoklatan. Hal tersebut dikarenakan tepung onggok terfermentasi memiliki warna putih kecoklatan sehingga berpengaruh terhadap warna crackers. Selain itu warna kecoklatan pada crackers disebabkan oleh reaksi Mailard (Akbar dan Yunianta (2014) yang terjadi pada proses pemanggangan sehingga warna umum crackers adalah kuning kecoklatan. Pengaruh substitusi tepung terigu dengan tepung onggok terfermentasi terhadap aroma crackers disajikan pada Gambar 4.

\section{Penerimaan Keseluruhan}

Hasil analisis ragam menunjukkan bahwa perlakuan substitusi tepung terigu dengan tepung onggok terfermentasi berpengaruh nyata terhadap skor penerimaan keseluruhan Hasil uji lanjut ortogonal contrast menunjukkan bahwa crackers dengan substitusi tepung onggok terfermentasi 5\% (b/b) dapat dikatakan memiliki skor penerimaan keseluruhan yang sama dengan crackers tanpa substitusi tepung onggok terfermentasi yang memiliki skor tertinggi.

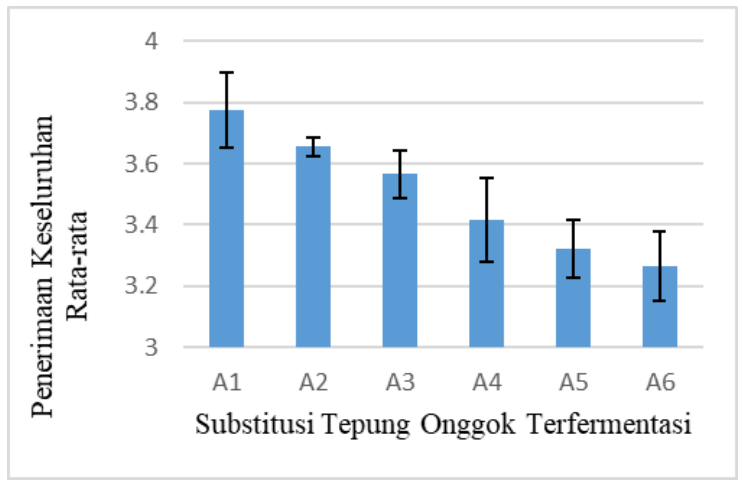

Gambar 5. Pengaruh substitusi tepung terigu dengan tepung onggok terfermentasi terhadap penerimaan keseluruhan crackers

Keterangan:

1 = Sangat tidak suka; 2 = Tidak suka; 3 = Agak suka; 4 = Suka; 5 = Sangat suka

Substitusi tepung onggok, A1=0\%; A2=5\%; $\mathrm{A} 3=10 \% ; \mathrm{A} 4=15 \% ; \mathrm{A} 5=20 \%$; A6 $=25 \%$

Penurunan skor kesukaan panelis terhadap penerimaan keseluruhan crackers yang disubstitusikan dengan tepung onggok terfermentasi mulai dari 5\% disebabkan oleh respon panelis terhadap rasa, aroma, warna dan tekstur crackers. Menurut Wonggo (2010) suatu bahan pangan yang memiliki tekstur yang baik dan rasa yang enak akan dikonsumsi jika 
memiliki warna tidak menyimpang seperti warna aslinya begitu juga sebaliknya. Pengaruh substitusi tepung terigu dengan tepung onggok terfermentasi terhadap penerimaan keseluruhan crackers disajikan pada Gambar 5.

\section{Penentuan Perlakuan Terbaik}

Penentuan perlakuan substitusi tepung terigu dengan tepung onggok terfermentasi terbaik berdasarkan pada hasil pengamatan uji sensori terhadap crackers yang dihasilkan meliputi parameter warna, rasa, aroma, tekstur dan penerimaan keseluruhan. Penentuan perlakuan terbaik crackers substitusi tepung terigu dengan tepung onggok terfermentasi dapat dilihat pada Tabel 2 .

Tabel 2. Penentuan perlakuan terbaik sifat sensori crackers substitusi tepung terigu dengan tepung onggok terfermentasi

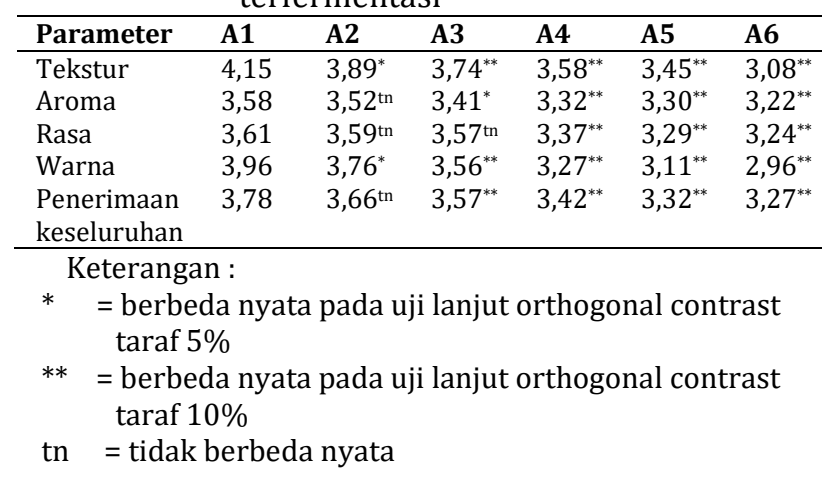

Tabel 2 menunjukkan bahwa perlakuan substitusi tepung terigu dengan tepung onggok terfermentasi 5\% (A2) menghasilkan crackers dengan aroma, rasa dan penerimaan keseluruhan tidak berbeda dengan crackers tanpa substitusi tepung onggok terfermentasi (A1), kecuali parameter tekstur dan warna berbeda.

\section{Analisis Kimia Perlakuan Terbaik}

Komposisi kimia crackers yang disubstitusi tepung onggok terfermentasi $5 \%$ dan SNI disajikan pada Tabel 3.

Tabel 3. Komposisi kimia crackers yang disubstitusi

\begin{tabular}{llll}
\multicolumn{4}{c}{ tepung onggok terfermentasi 5\% } \\
\hline Komponen & $\begin{array}{l}\text { Crackers } \\
\text { substitusi } \\
\text { tepung } \\
\text { onggok } \\
\text { terfermentasi }\end{array}$ & $\begin{array}{l}\text { SNI Biskuit } \\
2973-2011\end{array}$ & Keterangan \\
& $1,97 \%$ & Maks.5\% & Memenuhi \\
\hline Kadar Air & $1,98 \%$ & - & Memenuhi \\
Kadar Abu & $7,28 \%$ & Min.5\% & Memenuhi \\
Kadar Protein & $15,23 \%$ & - & Dapat diterima \\
Kadar Lemak & $73,54 \%$ & - & Dapat diterima \\
Kadar & & - & Dapat diterima \\
Karbohidrat & $7,30 \%$ & & \\
Total Serat & & & \\
Pangan & & & \\
\hline
\end{tabular}

Hasil analisis kimia pada Tabel 3. menunjukan bahwa crackers dengan substitusi tepung onggok fermentasi 5\% dapat diterima dan sesuai dengan Standar Mutu Biskuit SNI 2973-2011 pada kadar air dan kadar protein sedangkan untuk parameter lain tidak dipersyaratkan.

\section{Percobaan Lanjutan}

Crackers yang dihasilkan dari perlakuan substitusi tepung onggok terfermentasi sebesar $5 \%(\mathrm{~b} / \mathrm{b})$, diaplikasikan pada onggok industri dan difermentasi dengan cara yang sama. Kedua crackers tersebut karakteristiknya diuji dengan uji pasangan. Hasil uji tersebut dapat dilihat pada Tabel 4.

Tabel 4. Uji pasangan crackers yang disubstitusi tepung onggok penelitian terfermentasi perlakuan $5 \%$ dan crackers yang disubstitusi tepung onggok industri terfermentasi $5 \%$.

\begin{tabular}{ccc}
\hline Parameter & \multicolumn{2}{c}{ Respon } \\
\cline { 2 - 3 } & Berbeda & Sama \\
\hline Tekstur & 4 & 16 \\
Warna & 4 & 16 \\
Aroma & 3 & 17 \\
Rasa & 5 & 15 \\
\hline
\end{tabular}

Hasil uji pasangan tersebut menunjukan bahwa tesktur, warna, aroma dan rasa cracker yang disubstitusi tepung onggok industry terfermentasi $5 \%$ tidak berbeda dengan cracker yang disubstitusi onggok penelitian $5 \%$ ( $\geq 15$ panelis mengatakan sama). Penampakan dari crackers tepung onggok terfermentasi berbahan onggok penelitian dan onggok industri tepung tapioka disajikan pada Gambar 6. Hal ini menggambarkan bahwa onggok industri punya potensi besar untuk dimanfaatkan sebagai bahan substitusi tepung terigu pada pembuatan crackers.

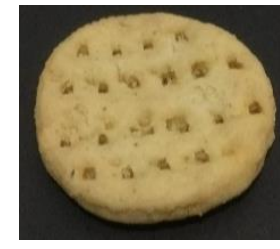

(a)

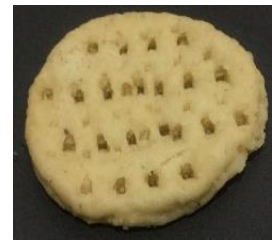

(b)
Gambar 6. Crackers yang disubstitusi tepung onggok terfermentasi buatan sendiri (a) dan onggok industri tepung tapioka PD. Semangat Jaya Pesawaran terfermentasi (b) 
Hal tersebut diduga karena kedua tepung onggok fermentasi mempunyai karakteristik yang hamper sama, ditunjukkan dengan nilai $\mathrm{pH}$ kedua tepung mendekati kesamaan yaitu 5,64 dan 5,70. Selain itu warna kedua tepung onggok terfermentasi memiliki warna putih abu-abu kecoklatan (Gambar 7).

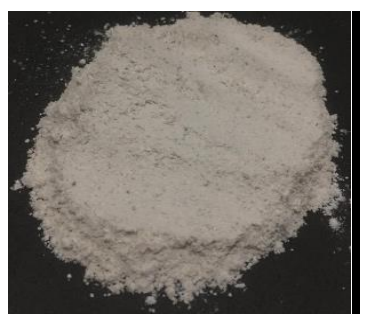

(a)

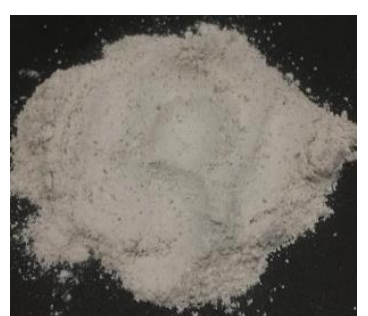

(b)
Gambar 7. Tepung onggok penelitian terfermentasi(a) dan tepung onggok industri terfermentasi

Crackers dengan substitusi tepung onggok penelitian terfermentasi 5\% mempunyai karakteristik tekstur renyah $(3,89)$, aroma disukai $(3,52)$, rasa disukai $(3,59)$, warna disukai $(3,76)$, penerimaan keseluruhan disukai $(3,66)$, kadar air $1,97 \%$, kadar abu $1,98 \%$, kadar protein 7,28 \%, kadar lemak 15,23\%, kadar karbohidrat $73,54 \%$ dan total serat pangan 7,30\%. Hasil uji pasangan crackers dengan substitusi tepung onggok industri terfermentasi 5\% memiliki karakteristik tekstur, aroma, rasa dan warna yang sama dengan crackers substitusi tepung onggok penelitian terfermentasi $5 \%$.

\section{Kesimpulan}

Crackers dengan substitusi tepung onggok penelitian terfermentasi 5\% mempunyai karakteristik tekstur renyah $(3,89)$, aroma disukai $(3,52)$, rasa disukai $(3,59)$, warna disukai $(3,76)$, penerimaan keseluruhan disukai $(3,66)$, kadar air $1,97 \%$, kadar abu $1,98 \%$, kadar protein 7,28 \%, kadar lemak 15,23\%, kadar karbohidrat $73,54 \%$ dan total serat pangan 7,30\%. Hasil uji pasangan crackers dengan substitusi tepung onggok industri terfermentasi 5\% memiliki karakteristik tekstur, aroma, rasa dan warna yang sama dengan crackers substitusi tepung onggok penelitian terfermentasi $5 \%$.

\section{Daftar Pustaka}

Afianti, F. dan Indrayani,V. Afianti, F. dan Indrayani,V. 2015. Pengaruh Penambahan Tepung Ikan Gabus
(Ophiocephalus striatus) dan Air terhadap Sifat Organoleptik Crackers. Jurnal Boga 4(1):46-55

Akbar, M.R., dan Yunianta. (2014). Pengaruh Lama Perendaman Na2S205 dan Fermentasi Ragi Tape terhadap Sifat Fisik Kimia Tepung Jagung. Jurnal Pangan dan Agroindustri 2(2): 91-102

Andarwulan, N. (2011). Garam dan Gula dalam Adonan Roti. Jurusan Ilmu dan Teknologi Pangan Fakultas Teknologi Pertanian IPB. Bogor

AOAC (Association of Official Analytical Chemists). (1995). Official Methods of Analysis of the Association of Official Analytical Chemists. Chemist Inc. New York.

Badan Standar Nasional (BSN). (1992). SNI 012891-1992. Cara Uji Makanan dan Minuman. BSN. Jakarta.

Badan Standar Nasional (BSN). (2011). SNI 2973-2011. Biskuit. BSN. Jakarta.

Badan Standar Nasional (BSN). (2011). SNI 7622-2011. Tepung Mokaf. BSN. Jakarta.

BPS. (2016). Data produksi ubi kayu Indonesia. http://bps.go.id/_linkTableDinamis/ view/id/880. Diakses tanggal 14 Agustus 2018

Fahmi, N dan Nurrahman. (2011). Kadar Glukosa, Alkohol dan Citarasa Tape Onggok Berdaasarkan Lama Fermentasi. Jurnal Pangan dan Gizi Vol. 02 No.03: 2541

FAO. (2001). Impact of Cassava Processing on the Environment, in Strategic environmental assessment,FAO Corporate Document Repository. http://www.fao.org/, diakses tanggal 15 Agustus 2018

Hadi, D.T. (2017). Analisis Sifat Kimia dan Fungsional Pasta Pati Singkong Termodifikasi dengan Fermentasi Saccharomyces cerevisiae. (Skripsi). Jurusan Teknologi Hasil Pertanian. Fakultas Pertanian. Universitas Lampung. Lampung. http://digilib.unila.ac.id/29564/. Diakses pada tanggal 3 Maret 2019.

Hidayat, B., Hasanudin, U., Nurdjanah, S. dan Yuliana, N. (2018). Improvement of Cassava Bagasse Flour Characteristics to Increase Their Potential Use as Food. IOP Conference Series: Earth and 
Environmental Science 209 (012006). doi:10.1088/1755-1315/209/1/012006

Izah, S. C., Bassey, S. E. and Ohimain, E. I. (2017). Cyanide and Macro-Nutrients Content of Saccharomyces cerevisiae Biomass Cultured in Cassava Mill Effluents. International Journal of Microbiology and Biotechnology, 2(4):176-180.

Jariyah, T., Mulyani dan Setya, P.P. (2013). Kajian Nutrisi Crackers Tepung Gayam. Jurnal Rekapangan 7(1):76-90

Kaewwongsa, W., Traiyakun , S., Yuangklang, C., Wachirapakorn, C., and Paengkoum, P. (2011). Protein Enrichment of Cassava Pulp Fermentation by Saccharomyces cerevisiae. Journal of Animal and Veterinary Advances, 10 (18):2434-2440

Khatarina, S. (2018). Kajian Substitusi Tepung Umbi Suweg (Amorphophallus campanulatus B) pada Pembuatan Crackers terhadap Sifat Kimia dan Organoleptik. Unpublished Skripsi. Fakuktas Pertanian, Universitas Lampung. Lampung.

Nurainy, F dan Nawansih, O. (2006). Buku Ajar Uji Sensori. Universitas Lampung. Bandar Lampung.

Nurdjanah,S dan Elfira, W. (2009). Profil, Komposisi dan Sifat Fungsional Serat Pangan dari Ampas Ekstraksi Pati Beberapa Jenis Umbi. Jurnal Teknologi Industri dan Hasil Pertanian 14(1):12-22.

Okaviana, A.S. Hersoelistyorini, W dan Nurhidajah. (2017). Kadar Protein, Daya Kembang dan Organoleptik Cookies dengan Substitusi Tepung Mocaf dan Tepung Pisang Kepok. Jurnal Pangan dan Gizi 7 (2): 72-81.

Olaoye, O.A., Lawrence, I.G., Cornelius, G.N. and Ihenetu , M.E. (2015). Evaluation of Quality Attributes of Cassava Product (Gari) Produced At Varying Length of Fermentation. American Journal of Agricultural Science, 2(1) 1-7.

Schmidl, K.M., dan Labuza, P.P. (2000). Essential of Functional Foods. Aspen Publisher, Inc. Gaithersburk. Maryland.

Subandoro, R.H., Basito dan Atmaka, W. (2013). Pemanfaatan Tepung Millet Kuning Sebagai Substitusi Tepung Terigu dalam Pembuatan Cookies Terhadap Karakteristik Organoleptik dan Fisikokimia. Jurnal Teknosains Pangan 2(4).
Suliantri dan Winiarti. (1991). Teknologi Fermentasi Biji-bijian dan Umbi-umbian. Departemen P dan K Direktorat Jendral Pendidikan Tinggi Pusat Universitas Pangan dan Gizi IPB. Bogor.

Sulistyowati, E., Wijaningsih, W. dan Mintarsih, S.N. (2015). Pengaruh Substitusi Tepung Kedelai dan Tepung Ikan Teri terhadap Kadar Protein dan Kalsium Crackers. Jurnal Riset Kesehatan 4 (3):813-818.

Wonggo, D. 2010 . Penerimaan Konsumen Terhadap Selai Rumput Laut (Kappaphycus alvarezzi) . Jurnal Perikanan dan Kelautan 6(1): 51-53 